Boletín de la Sociedad Geológica Mexicana

VOLUMEN 64, NÚM. 2, 2012, P. 189-197

\title{
Paleopedogenesis during the Mikulino interglacial (MIS 5e) in the East-European plain: buried toposequence of the key-section "Alexandrov quarry"
}

\author{
Svetlana Sycheva ${ }^{1}$, Sergey Sedov ${ }^{2, *}$ \\ ${ }^{1}$ Institute of Geography, RAS. Staromonetny 29, Moscow, 119017, Russia \\ ${ }^{2}$ Instituto de Geología, Universidad Nacional Autónoma de México, México \\ *serg_sedov@yahoo.com
}

\begin{abstract}
The Alexandrovsky quarry exposure (near Kursk, central European Russia) represents one of the most complete and detailed records of paleosols, colluvial sediments and loess for the last glacial-interglacial cycle in Eastern Europe. The buried toposequence of Mikulino (Eemian) paleosols, developed on a gully slope cut in the Dnepr (Riss) loess and overlain by Early Valdai (Würmian) colluvium, was subjected to detailed morphological study. The paleosol on the upper slope is an Albeluvisol that contrasts from the Holocene Chernozem. Analysis of thin sections of the Albeluvisol demonstrated that elluvial features - concentrations of bleached silt in the pores and in the groundmass - dominate not only in $\mathrm{E}$ and $\mathrm{EB}$ but also in the $\mathrm{Bt}_{1}$ horizon. They also penetrate into lower $\mathrm{Bt}_{2}$ and $\mathrm{Bt}_{3}$ horizons where they combine with illuvial clay pedofeatures. The paleosol profile at the bottom of the gully shows synsedimentary development with several A, AE and E horizons reflecting several phases of geomorphic activity as a response to a complex environmental history during the last interglacial. The shift from dark humus accumulation under grasslands towards forest pedogenesis dominated by clay illuviation and stagnic processes comprised the major trend of the Mikulino (Eemian) soil evolution.
\end{abstract}

Keywords: Paleopedogenesis, Eemian soil, Mikulino soil, catena, Albeluvisol, last interglacial.

Resumen

El perfil en la cantera Alexadrovsky (cerca de Kursk en el centro de Rusia europea) representa el registro más completo y detallado para el último ciclo glacial-interglacial en Europa Oriental, formado por paleosuelos, sedimentos coluviales y loess. Se ha realizado un estudio morfológico detallado de la toposecuencia sepultada de los paleosuelos Mikulino (Eemian), desarrollada sobre la ladera de una barranca en el loess Dnepr (Riss) y cubierta por el coluvión de Valdai Temprano (Würm). El paleosuelo en la parte superior de la ladera es un Albeluvisol que demuestra una diferencia contrastante con el Chernozen holocénico. Según las observaciones en las láminas delgadas del Albeluvisol, los rasgos de eluviación - concentraciones de limo blanqueado en los poros y en la matriz - dominan no solo en los horizontes $E$ y EB sino también en el $B t_{1}$. Ellos penetran en los horizontes subyacientes $B t_{2} y B_{3}$ en donde se combinan con las concentraciones de arcilla iluviada. El perfil del paleosuelo en el fondo de barranca muestra un desarrollo sinsedimentario con múltiples horizontes $A, A E$ y E que reflejan las fases de actividad geomorfológica como respuesta a la historia paleoambiental compleja del último interglacial. El cambio de acumulación de humus oscuro bajo pastizales hacía pedogédesis boscosa, dominada por la iluviación de arcilla y los procesos estágnicos, conformó la tendencia principal de la evolución del paleosuelo Mikulino (Eemian).

Palabras clave: Paleopedogénesis, suelo Eemian, suelo Mikulino, catena, Albeluvisol, último interglacial. 


\section{Introduction}

Paleosols of the last interglacial period (Riss-Wurm, Mikulino, Eemian, Sangamon), correlated with the Marine Isotope Stage (MIS) 5e, are frequently preserved in regions that are not subjected to the direct impact of the Valdai, Wurm, and Wisconsin glaciations, such as in the periglacial and extraglacial zones of Eurasia and North America. They are known in Russia as Ryzhkovo (Mikulino) or Salyn paleosol; in West Siberia as Berdsk paleosol; in Ukraine as Gorokhov and Kaidak paleosols; and in Poland as Netulisko 1. In the Czeck Republic these paleosols are recognized as PK II; in Austria as the Stillfried A; in Belgium as Rocourt, and as Sangamon in the USA, among others (Velichko and Morozova, 1985; Gerasimenko, 2004; Glushankova, 2008; Morozova, 1981; Zykina, 2007; Sycheva, 1985, 1994; Bibus, 1999; Demek and Kukla, 1969; Haesaerts and Mestdagh, 2000; Kukla and Koci, 1972; Paepe and Vanhoorne, 1967; Pécsi and Richter, 1996, Terhorst et al., 2011). These soils are an important late Pleistocene stratigraphic marker.

Properties of paleosols in the loessic sequences record the pedogenetic processes controlled by interglacial climates together with the burial impact and post-burial diagenetic transformations. Duration of the Mikulino interglacial ( 130-118 ky BP) slightly differs from that of the Holocene (11 ka). In the case of the Mikulino interglaciation, we are dealing with the complete evolution of an interglacial soil from parent material to interruption of pedogenesis by periglacial sedimentation. However, identification of all stages of soil formation and reconstruction of the complete environmental history meets certain difficulties.

In Europe, MIS 5e paleosols are mostly studied in the individual profiles of watersheds, the upper parts of slopes, and ancient terraces, where they frequently present brown Bt horizons. Their elluvial horizons are only partly preserved. Upper humus horizons may be destroyed by denudation processes or combined with humus horizons of early Valdai interstadial soils forming a pedo-litho-complex. This limits finding evidence of the last stages of pedogenesis corresponding to the interglacial - glacial transition.

More opportunities for detailed reconstruction of pedogenesis and landscape evolution are provided by the research of the paleosol toposequences, which until now have been very few. A detailed picture of evolutionary stages not recorded in the profile of watershed soils can be observed in the bottom of small buried erosive forms, the lower parts of slopes and other accumulative geomorphic positions (Sycheva, 1994; Sycheva and Gunova, 2004; among others).

A new more detailed stratigraphic scheme was defined based on the investigation of late Pleistocene sediments in paleocut infillings in the Middle Russian upland (Sycheva and Gunova, 2004; Sycheva et al., 2007). Table 1 shows the correlation of late Pleistocene schemes for loess and glacial regions of the east-European plain and MIS (1 to 5e) of oceanic sediments.

Within the paleo-toposequences there are sites and conditions where Mikulino paleosols are the most completely preserved. We studied a toposequence corresponding to the Ryzhkovo (Mikulino) soil complex at the bottom and on the slopes of a buried balka (gully) in an extensive exposure of the Alexandrov quarry near Kursk, central Russia to reconstruct a detailed scheme of the interglacial soil mantle development in relation to landscape evolution. The following research tasks were formulated:

1) Reconstruction of soil genesis: recognition of the set of pedogenetic processes for the Ryzhkovo (Mikulino) soil complex.

2) Study of the variability of Mikulino paleosols in the toposequence along the slope of the buried MoscowMikulino paleodepression.

3) Understand the interaction of paleo-pedogenesis with the surface geomorphic processes (erosion and sedimentation) in order to reconstruct the main phases of landscape evolution during the Mikulino interglacial.

\section{Objects and methods}

Ryzhkovo (Mikulino) soil is well preserved along the slopes and bottom of a buried paleobalka below a $5 \mathrm{~m}$ pedosediment in the Alexandrov quarry $\left(51^{\circ} 05^{\prime} \mathrm{N}, 36^{\circ} 08^{\prime}\right.$ $\mathrm{E}, 200-220 \mathrm{~m}$ a.s.1.). Alexandrov quarry is the major section representing the late Pleistocene and was recognized as a geological monument on a regional scale (Sycheva and Gunova, 2004). The quarry is situated in the Middle Russian Upland, on the Seim and Mlodat interfluves, $10 \mathrm{~km}$ south of Kursk (Figure 1). The modern soils of the region are represented by three soil units along the landscape: Haplic Chernozems in the higher land surface positions; Haplic and Luvic Phaeozems on the watersheds and balka slopes, and Gleyic Phaeozems on the bottom of the depressions (IUSS Working Group WRB, 2006).

The thickness of the whole section at the bottom of the gully is more than $10 \mathrm{~m}$, with the following layers from top to bottom (Figure 2):

I. Holocene Haplic Chernozem on the main land surface with $\mathrm{A}_{1}$-AB-Bk horizons; the soil at the bottom of the paleo-depression is a Luvic Phaeozem, showing $A_{1}-A B-B t$ horizons, $150-170 \mathrm{~cm}$ thick.

II. Late Valdai pale brown loess, $50-80 \mathrm{~cm}$ thick. The ${ }^{14} \mathrm{C}$-age (not calibrated) obtained for its upper part is 11140 \pm 190 yr BP (Ki-9360), $12200 \pm 180$ yr BP (Ki-9361).

III. Bryansk interstadial paleosol - periglacial foreststeppe sod-carbonate cryogenic disturbed soil with wedgeshaped structures: the $\mathrm{A}_{1}-\mathrm{Bk}-\mathrm{Bg}-\mathrm{Cg}$ horizons are 60-80 up to $110 \mathrm{~cm}$ thick. Its ${ }^{14} \mathrm{C}$-age (not calibrated) is $33140 \pm 230$ yr BP (Ki-8211).

IIIa. Tuskar gleyed loess is developed above the paleogully bottom; $30-50 \mathrm{~cm}$ thick. This layer contains bone fragments of prehistoric horses and woolly rhinoceros with 
Table 1. Correlation of stratigraphic schemes for Late Pleistocene glacial and loess regions of the East-European plain and Marine isotope stages (MIS).

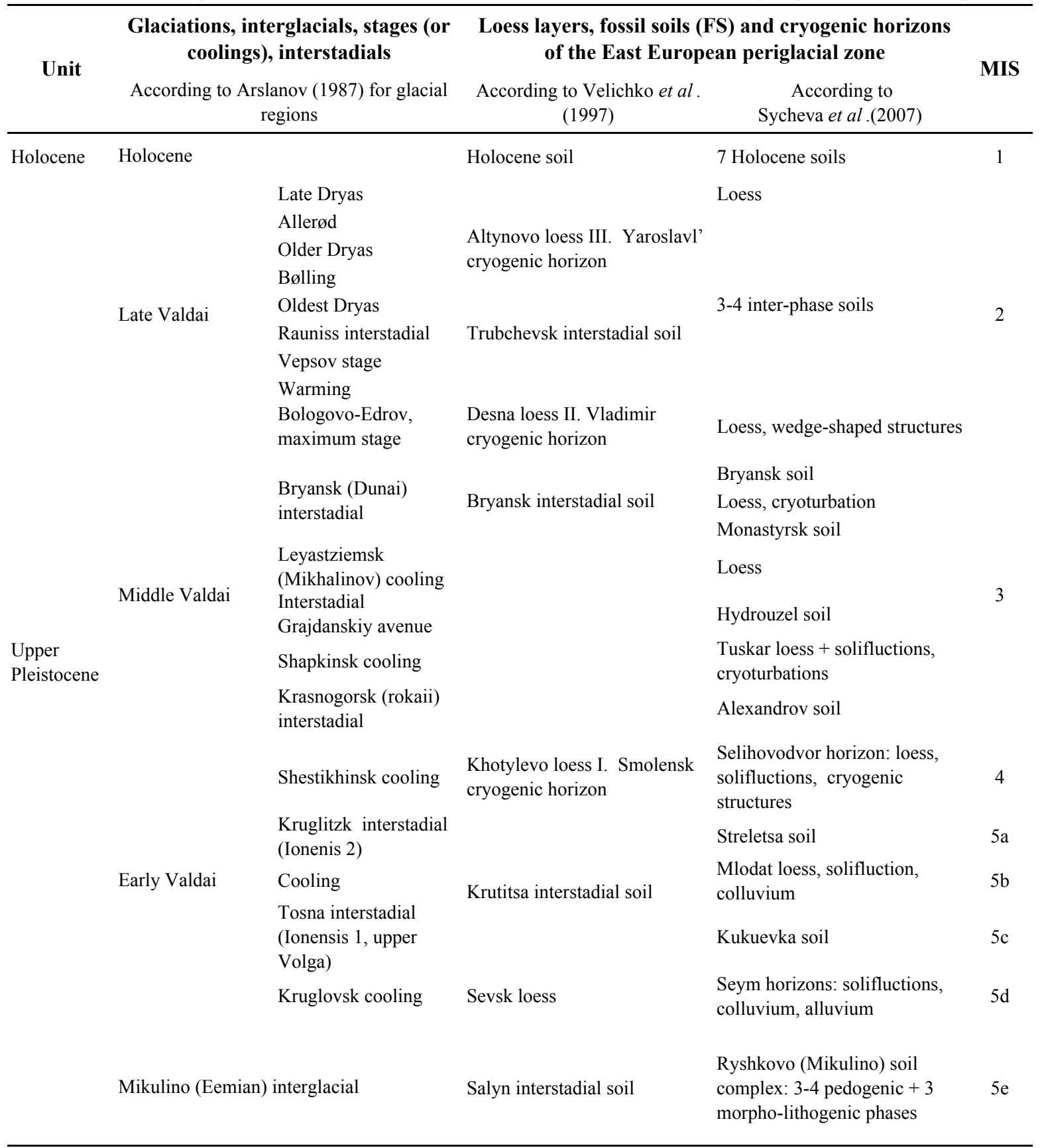

${ }^{14} \mathrm{C}$-ages (not calibrated) of $39710 \pm 580 \mathrm{BP}(\mathrm{Ki}-9362)$ and $40200 \pm 420$ yr BP (Ki-10868).

IV. Alexandrov interstadial paleosol - forest-steppe wet-meadow soil with solifluction deformations: $\mathrm{A}_{1}-\mathrm{Bg}-\mathrm{Cg}$; $40-60 \mathrm{~cm}$ thick. Its ${ }^{14} \mathrm{C}$-age is $49500 \pm 520 \mathrm{yr} \mathrm{BP}(\mathrm{Ki}-15275)$ and $>53000$ yr BP (Ki-15274).

IVa. Selihovodvor horizon - pedosediment of Streletsa paleosol with cauldron-shaped pseudomorphs breaking up Streletsa and Kukuevka paleosols; 10-70 cm thick.

V. Streletsa interstadial paleosol - forest-steppe meadow-Chernozem soil with ground veins (humus tongues): $\mathrm{A}_{1}-\mathrm{ABk}-\mathrm{BC} ; 60 \mathrm{~cm}$ thick, up to $130 \mathrm{~cm}$ together with pedosediment.

Va. Mlodat horizon - pedosediment of Kukuevka paleosol; 10-25 cm thick.

VI. Kukuevka interstadial paleosol - forest-steppe meadow-Chernozem soil: $A_{1}-B C$ sometimes with small tongues; $20-25 \mathrm{~cm}$ thick, up to $30-50 \mathrm{~cm}$ thick together with pedosediment.

VII. Seym horizon - early Valdai solifluction-colluvial loams together with pedosediments of Mikulino soil; 300$400 \mathrm{~cm}$ thick. 
VIII. Ryzhkovo (Mikulino) interglacial paleosol.

According to the available radiocarbon dates, pollen data (Sycheva and Gunova, 2004; Sycheva et al., 2007) and morphotypic characteristics, it is possible to correlate the interstadial and interglacial soils with the "warm" stages of MIS curve and the loess layer with the "cold" stages: Valdai loess with MIS 2, Bryansk soil with MIS 3, Streletsa with MIS 5a, Kukuevka with MIS 5c, Mikulino with MIS 5e,

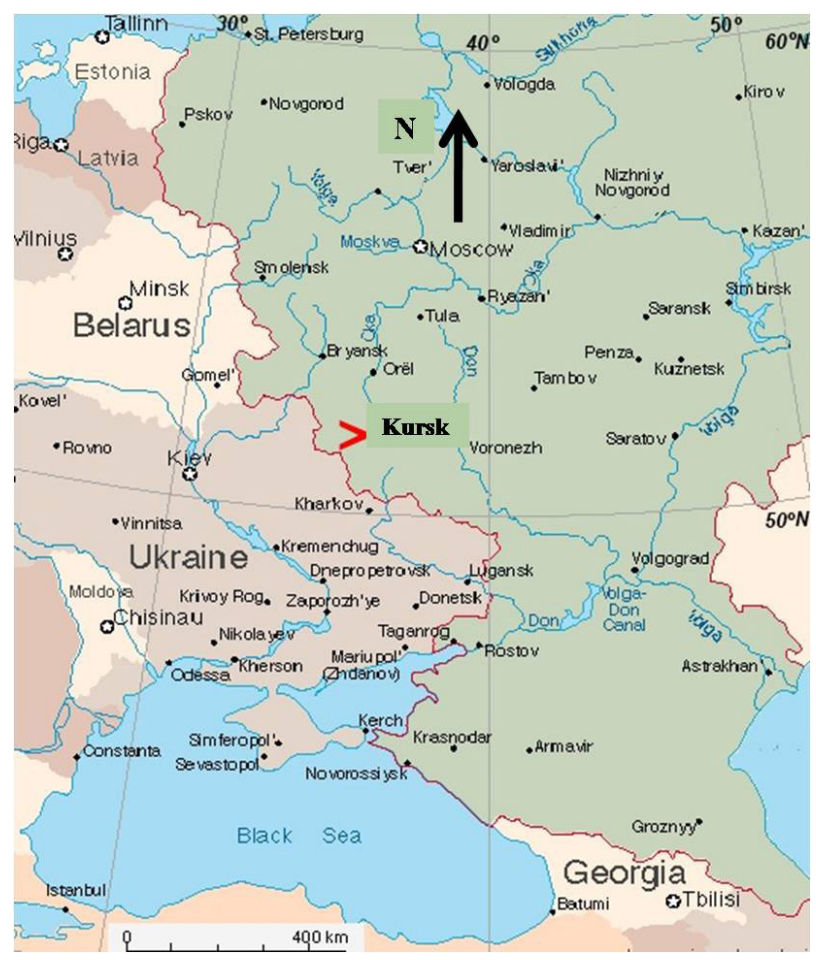

Figure 1. Geographic location of the Alexandrovsky quarry, near Kursk in the East Russian plain. and Dnieper loess with MIS 6.

The main method of investigation was the macromorphological study of Ryzhkovo (Mikulino) soil profiles along the toposequence, following the main mesoand microrelief elements: slopes and the bottom of the balka. Various elements of buried micro- and nanorelief are represented in the bottom of the balka, such as buried gully beds of various generations, and seasonally-frozen pseudomorphs. Soil profiles display differences at distances of 1-2 $\mathrm{m}$ and, therefore, were studied in soil pits dug at the same distance. More detailed investigation of soils at the bottom of Moscow-Mikulino paleodepression was completed for the thorough reconstruction of interglacial soil development. Micromorphological study was done in soil profile No. 15 in the upper part of the paleo-slope for a detailed investigation of paleosol genesis.

\section{Results}

The paleosurface of the buried Moscow-Mikulino paleodepression (paleobalka) is marked by Ryzhkovo (Mikulino) buried soil, which was perfectly preserved at the bottom and on the slopes due to rapid burial under Early Valdai colluviums (Figure 2).

A general scheme of the paleotoposequence is presented in Figure 3. Ryzhkovo (Mikulino) soil is not preserved beyond the limits of the buried balka. It appears on the balka slopes and was studied in a catena. The catena consists of several parts, which have strong differences in the structure of the Ryzhkovo (Mikulino) paleosol. In the highest position (pit 17), where the Ryzhkovo (Mikulino) soil has the most complete profile, its humus horizon, occurring at a depth of $3.2 \mathrm{~m}$, is largely reduced. Down the slope (pit 16) Mikulino

SE

NW

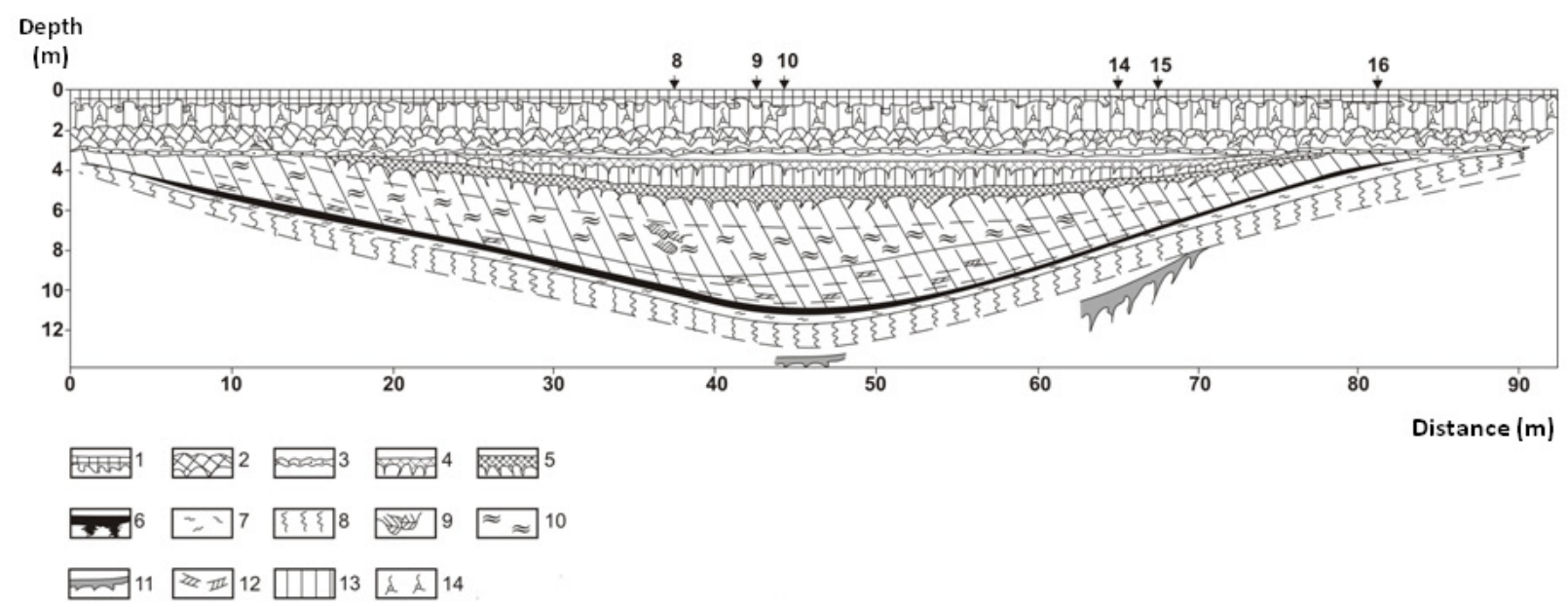

Figure 2. General stratigraphic scheme of the Alexandrovsky quarry exposure showing the location of the studied profiles:

1. Holocene Chernozem; 2. Bryansk paleosol; 3. Alexandrov paleosol; 4. Streletsa paleosol; 5. Kukuevka paleosol; 6-8. Ryzhkovo (Mikulino, Eemian) paleosol; 6. A horizon; 7. E horizon; 8. Bt horizon; 9. Zooturbation; 10. Solifluction features; 11. Deformed middle Pleistocene paleosol; 12. Pedosediments from Eemian paleosol; 13. Late Valdai loess; 14. Secondary carbonates. 


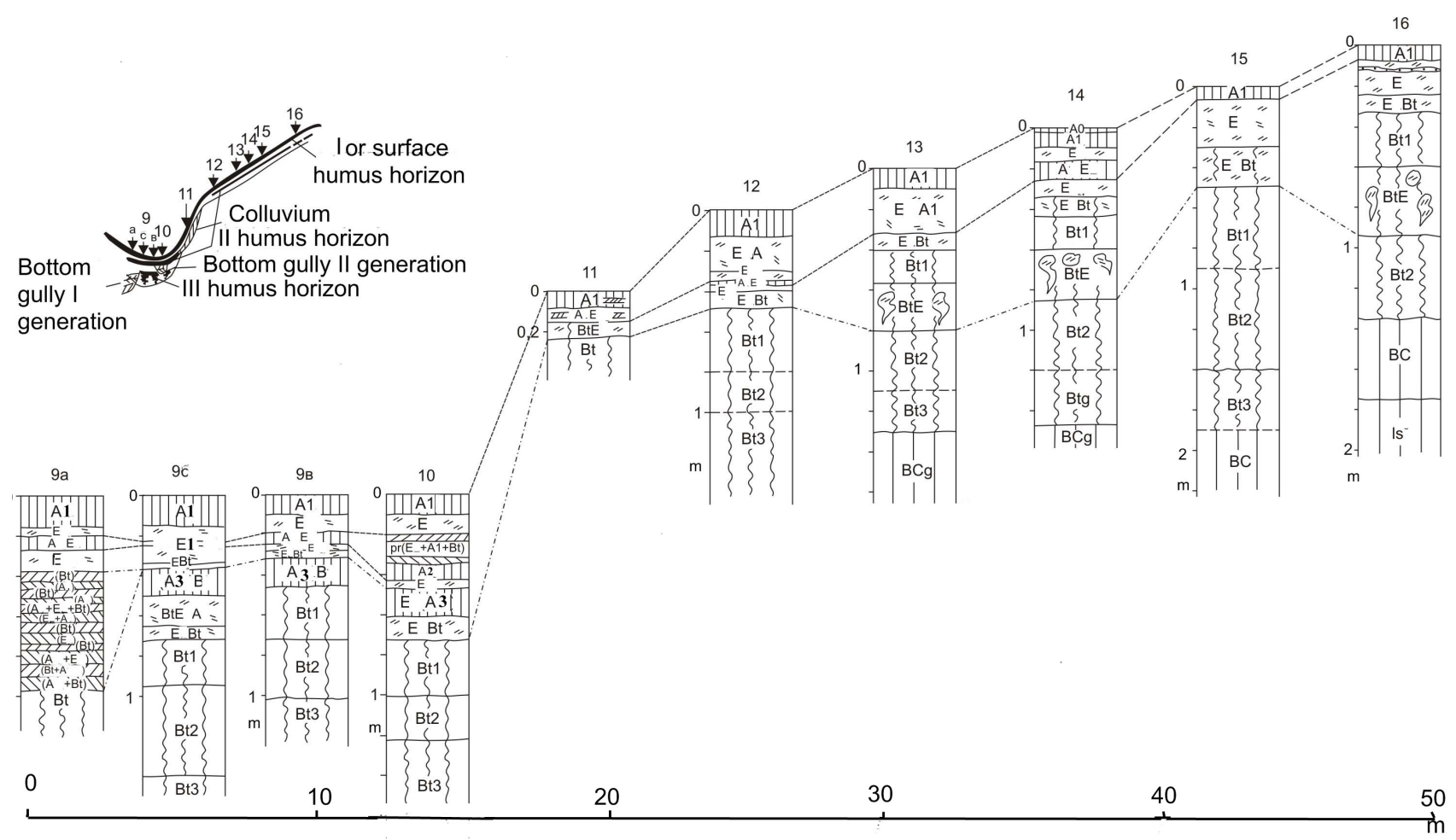

Figure 3. Schematic diagrams of the Eemian paleosol profiles and their distribution along the toposequence.

is present at a depth of $4.5 \mathrm{~m}$ under a yellowish loamy colluvial stratum; it preserves a complete horizon sequence (Figure 3). Its profile includes a $7 \mathrm{~cm}$ thick dark gray, heavy loam, sticky, heterogeneous humus-accumulative horizon, with lens of charred material. A humus-elluvial horizon occurs below and, like the horizon above, it is strongly disturbed by soil fauna. It is underlain by a $17 \mathrm{~cm}$ thick elluvial whitish-pale light loamy horizon. This horizon has two narrow dark-gray layers with flake structure, many large charred particles up to $0.5-1 \mathrm{~cm}$ in size, and black and brown microconcretions embedded into the whitish powder which compose the horizon. A transitional elluvial-illuvial EBt horizon $(24-34 \mathrm{~cm})$ lies below. It is a light brown, silty loam, with a flake-fine angular blocky structure. A thick set of illuvial $\mathrm{Bt}$ horizons is developed below: $\mathrm{Bt}_{1}(34-95$ $\mathrm{cm}$ ) - dark brown, silty loam, fine, angular; $20-30 \mathrm{~cm}$ diameter spots consisting of bleached material are present. The bright brown, clay-loamy illuvial horizon $\mathrm{Bt}_{2}$ (95-135 $\mathrm{cm}$ ) is more finely textured. At a depth of $135-175 \mathrm{~cm}$, a $\mathrm{BC}$ horizon is found. Mikulino is underlain by Dnepr (Riss) loess (pale calcareous silty loam with well expressed postice lens texture).

Ryzhkovo (Mikulino) soil has the simplest profile in pit 15 , situated on the gentle slope: $\mathrm{A}_{0}(01 / 1.5 \mathrm{~cm})-\mathrm{A}_{1}(1-5 / 7)$ $\mathrm{cm}-\mathrm{E}(5-30 \mathrm{~cm})-\mathrm{EBt}(30-50 \mathrm{~cm})-\mathrm{Bt}_{1}(50-90 \mathrm{~cm})-\mathrm{Bt}_{2}$ $(90-140 \mathrm{~cm})-\mathrm{Bt}_{3}(140-170 \mathrm{~cm})$. In this pit Mikulino is underlain by middle Pleistocene Kamensk soil with $\mathrm{A}_{1}$ and $\mathrm{Bt}$ horizons. The most reduced profile was found on the slope in pit 11 (Figure 3).
Multistage development of Ryzhkovo (Mikulino) paleosol is more evident in the lower part of the slope and bottom of the balka. Ryzhkovo (Mikulino) soil in pit 9c is represented by three profiles. The lower profile represents meadow soil; the second and third profiles are texturallydifferentiated (sod-podzolic) soils: $\mathrm{A}_{1}(8-18 \mathrm{~cm})-\mathrm{E}_{1}(18-27$ $\mathrm{cm})-\mathrm{AE}(27-31 \mathrm{~cm})-\mathrm{E}_{2}(31-35 \mathrm{~cm})-\mathrm{EBt}(35-39 \mathrm{~cm})-$ $\mathrm{ABt}(39-54 \mathrm{~cm})-\mathrm{Bt}_{1}(54-80 \mathrm{~cm})-\mathrm{Bt}_{2}(80-110 \mathrm{~cm})-\mathrm{Bt}_{3}$. Bottom gullies of several generations were described in pits 9a, 9b, 9c (Figure 3).

Pit 10 exposes the lower part of the catena - the bottom of balka. A second generation gully bed, related to a cryogenic wedge (evidence of seasonal inter-Mikulino frost), was found here. Pit $10 \mathrm{~d}$ corresponds to such cryogenic features.

The upper part of the Mikulino soil, horizons $\mathrm{A}_{1}(0-6 \mathrm{~cm})$ and $\mathrm{E}_{1}(6-14 \mathrm{~cm})$, is affected by wedge-shaped deformation. The wedge is $30 \mathrm{~cm}$ wide. In the upper part, it penetrates to a depth of $15 \mathrm{~cm}$; however, a narrow crack at its bottom extends downward another $120 \mathrm{~cm}$. This cryogenic wedge has a heterogeneous infilling: a lighter colluvial layer (14$24 \mathrm{~cm}$ ) intercalated with darker humus-rich and ferruginous materials. The most humus-rich material is $5 \mathrm{~cm}$ thick and is related to the lower part of the wedge. The lowest profile of the Mikulino pedocomplex includes the following horizons: $\mathrm{E}_{2}(49-65 \mathrm{~cm}), \mathrm{Bt}_{1}(70-100 \mathrm{~cm}), \mathrm{Bt}_{2}(100-124 \mathrm{~cm})$, and $\mathrm{Bg}$ $(124-180 \mathrm{~cm})$.

Micromorphological observations were made in all genetic horizons of profile 15. Lower colluvial sediment consists mostly of bleached silty material similar to the 
groundmass of E horizon. It contains compound ferruginous pedofeatures as clusters of rounded compact segregations, and has rare large biopores - chambers with mesofauna excrements (Figure 4a). Upper brown colluvial sediment contains clay papules - fragments of illuvial clay coatings derived from Bt horizons (Figure 4b).

The microstructure of A horizon is very complex with a combination of isometric crumby and platy aggregates, and humus-clayey fine material. Organic pigment has a heterogeneous distribution with interchanging of darkcolored and light-colored micro-zones. There are few signs of fauna activities: some zoogenic channels with excrement infillings were found. The groundmass contains various charred particles: large wooden particles and small elongated particles possibly having a grass origin.

E horizon demonstrates very well developed and preserved fine platy structure. Aggregates show clear textural differentiation with prevailing coarse silt in the upper parts, and fine silts and plasmic material in the lower ones. Many compact rounded simple iron segregations are widespread in the groundmass.

EBt horizon has a well-developed platy structure (Figure 4c) like the overlying E horizon. The groundmass contains fine material concentrated inside the plates, while the peripherical parts consist of bleached silt. Iron pedofeatures are variable, such as rounded segregations or incrustations of platy aggregates mainly along the bottom part.

$\mathrm{Bt}_{1}$ horizon still has the platy aggregation, but plates become thicker and friable, often parting into angular blocks. Intra-aggregate pores have common bleached silty coatings and infillings, and common iron segregations in the matrix. The fragments of illuviated clay were noted in the interpedal mass enriched in fine material, but we did not find any undisturbed clay illuvial pedofeatures still related to the pores (Figure 4d).

$\mathrm{Bt}_{2}$ and $\mathrm{Bt}_{3}$ horizons only have the undisturbed layered illuvial clay coatings, which are mostly concentrated inside interaggregate voids. Many illuvial pedofeatures
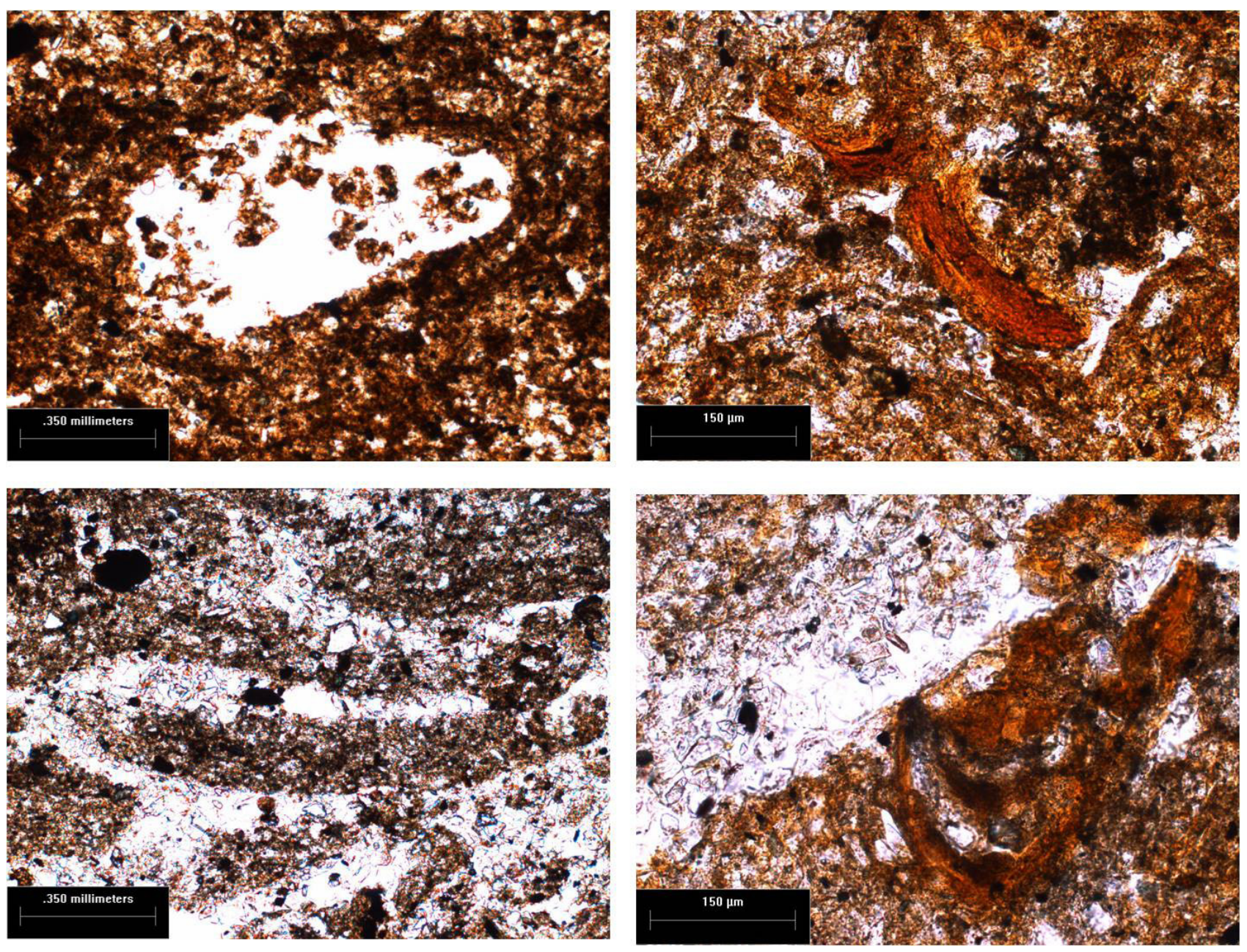

Figure 4. Micromorphology of Mikulino paleosol and overlying sediments

a) Biopore with the infilling of coprogenic aggregates, lower colluvial layer.

b) Fragment of clay cutan, upper colluvial layer.

c) Platy structure, EBt horizon.

d) Bleached silt in the pore, deformed clay coating incorporated in the groundmass, $\mathrm{Bt}_{1}$ horizon. 
are deformed and fragmented. Bleached silt grains are still abundant and concentrated mainly in the fissures and large channels. They have abrupt boundaries with the groundmass, and sometimes they are superimposed on the clay coatings. Bleached silty zones with diffuse boundary also occur.

\section{Discussion}

4.1. Mikulino paleosol variability along a catena: interaction of pedogenesis and geomorphic processes

Variations in Mikulino soil can be observed in the catena along the slope of south-east exposition and in the bottom of the buried balka. The changes remain within the single type of forest texturally-differentiated soil. The main differences are related to the degree of evolutionary development, which in turn depends upon the variable combinations of soil forming processes and geomorphic, cryogenic, denudation and sedimentation processes. Pit 16 in the upper part of the slope already reveals the clear lithological heterogeneity of the parent material. This nonuniformity is quite explainable for two reasons: cryogenic icy sorting in the lower part (formation of ice lenses and their further replacement by silty layers), and gully-slope (fluvial and colluvial) genesis of the upper part of the profile during Moscow late glacial. The second reason can easily explain the occurrence of a second elluvial-illuvial horizon inside the illuvial one. This subhorizon is largely developed in certain spots on both slopes of the balka, starting from pit 16 .

Pit 15 is located at a relatively gentle part of slope. The primary layering of parent material is not expressed in the illuvial horizon, because it has almost been leveled by intensive soil forming processes.

Pits 14-12 are situated lower along the slope of the buried balka. The profile of Mikulino soil is more complicated with gray humus layers inside the E horizon. They represent the remnants of the second humus horizon. It is more clearly expressed in pit 12, where two elluvial horizons are presented. The illuvial horizon has krotovinas filled with the material from the third humus horizon, which is not present in this geomorphological position. It is most likely degraded. Clay rich low permeable middle Pleistocene soil underlying Mikulino soil caused the gleization of lower horizons in this part of the catena.

Pit 11 is situated on the steepest part of slope. Mikulino soil is strongly reduced here, and its humus horizon contains colluvial layers of interglacial age.

In pits 9 and 10, situated at the bottom of the balka, Mikulino is the most complicated and is presented by the profiles with three humus and two elluvial horizons. The lower $\mathrm{A}_{3}$ horizon transformed into illuvial humus-clayey $\mathrm{ABt}$ that acts as a transitional EBt horizon. It indicates the position of the primary (most ancient) bottom of the balka, when relief-forming processes were slow at first, permitting soil formation to start. The sequence of nongleyed illuvial horizons is developed below in the profile of primary bottom.

The Mikulino soil thickness at the bottom of the paleocut records erosional processes: two generations of gullies and frost processes. The gully bed of the first generation is represented in pit 9a. It is filled by layered material, which was directly related to the period before formation of $\mathrm{E}_{2}$ - the lower elluvial horizon on the slope of the balka (Figure 2). The bottom of the gully is rounded, not V - shaped, which indicates a long period of formation.

The remains of the third humus horizon in the gully infilling indicate that its formation started after the degradation of the third humus horizon during the phase of less favorable bioclimatic conditions. The evidence of structural deformation of seasonally frozen ground (small wedge-shaped structures) filled by layered material and breaking the second humus horizon indicates the next phase of environmental deterioration after the formation of the second humus horizon i.e. within a period of interglacial cooling, which was followed by an erosional stage.

All along the catena Ryzhkovo (Mikulino) soil is clearly separated from the overlying pedosediment by a pyrogenic horizon - litter subjected to a strong fire. Pedosediment strongly conserves the paleosol and is formed by redeposited $\mathrm{A}_{1}, \mathrm{E}, \mathrm{Bt}$, and $\mathrm{C}$ horizons of Mikulino soils that were earlier developed on slopes and interfluves. This permits us to state that clay-differentiated Albeluvisols were widespread on slopes and watersheds of this area during the Mikulino interglacial period. The composition of the pedosediment changes rhythmically (vertically and laterally) in the buried depression, reflecting the succession of erosion and re-deposition of various soil horizons. Thus, not only multiphase paleosol development during the interglacial period, but also the features of terminal processes (litter, pyrogenic layer), and a burial event (pedosediment as a result of accelerated heavy sheet erosion after fire) were recorded in the structure of the Mikulino paleocatena, and especially in the profiles in the bottom part of the balka.

\subsection{Pedogenesis of Mikulino Albeluvisol: micromorphological evidence}

The complex of weak but easily identified soil forming processes is related to the period immediately after the end of Luvisol formation and the beginning of colluvial sediment accumulation:

- zooturbation (presence of biopores and excremental aggregates) - mostly easily identified in the lower colluvial layer (Figure 4a),

- gleyization and segregation of iron (compound nodules in lower horizon, impregnation of aggregates in the upper layer),

- cryogenic structure, especially in the upper layer.

It is important to note that the morphology of the indicated features excludes the possibility of origin by 
redeposition. They were formed in situ under the influence of weak sedimentary soil formation which transformed the colluvial sediments. There are also features indicating redeposited material in various horizons:

- washed silty material in the lower layer derived from E horizon,

- fragments of illuviation cutans in the upper layer indicating that the material originated from illuvial-clayey horizons (Figure 4b),

- the microstructure of humus and elluvial horizons of Mikulino soil is very similar to Holocene forest Albeluvisols.

It is important that $\mathrm{E}$ and $\mathrm{EBt}$ horizons reproduce surprisingly clearly the fine platy microstructure (Figure 4c), which is characteristic of the elluvial layers of texturallydifferentiated soils of the modern taiga: inside the plates, coarser silty material on the upper side and fine material on the bottom. Such a structure is related to ice lenses during frost. Thus, the upper horizons of Mikulino soil were seasonally frozen at least during the final stages of its formation.

E and EBt horizons show evidence of iron segregation, which is also typical for loamy podzolic soils and is related to surface gleyization. Iron pedofeatures are much more variable in the EBt than in the E horizon. Specific iron films occur only on the lower sides of platy structures in EBt horizon. This may indicate an elluvial-illuvial redistribution of iron in the limit of the elluvial horizon, with its accumulation in the lower part (in the EBt horizon). It is interesting that this idea correlates well with data of the magnetic susceptibility pattern, which shows an absolute minimum in E horizon and strong maximum in EBt horizon (Rivas et al., 2006). This redistribution can be due to elluvial-gley processes, but does not exclude podzolization (migration of iron-humus complexes). Spodosol subprofiles included into the clay-elluvial horizon are known for taiga Albeluvisols.

The most interesting observations are related to the redistribution of clayey and bleached silty pedofeatures, which indicate profile differentiation due to elluviation and illuviation of fine material. E and EBt horizons represent a zone of complete prevalence of elluvial processes with the domination of washed coarse material, while the illuvial clay pedofeatures and even their fragments are absent. Meanwhile elluviation dominates in $\mathrm{Bt}_{1}$ horizon: all platy aggregates are covered by thick coatings consisting of bleached silt, while illuvial clay is present in deformed and fragmented pedofeatures and are not related to the contemporary pores (Figure 4d).

A certain parity between the indicators of elluvial and illuvial processes is noted for $\mathrm{Bt}_{2}$ and $\mathrm{Bt}_{3}$ horizons only where both bleached silt and undisturbed illuvial clay coatings are present. These processes have the tendency for inter-horizontal spatial differentiation: elluvial features are concentrated in large intra-aggregate pore-fissures, and illuviated clay is in the inter-aggregate channels. Morphology of bleached silt concentrations indicates two formation mechanisms: 1) residual concentration of bleached silt in situ after washing of the fine-dispersed components (example of diffuse boundary with the main mass) and 2) silt particle migration along the voids, after becoming washed from fine material (example of abrupt boundary and especially of silt superimposed on clay pedofeatures).

The distribution of silty and clay pedofeatures clearly indicates an active penetration of elluvial processes into $\mathrm{Bt}$ horizons (originally formed by illuvial processes), where they involve primarily the microzones surrounding the intra-aggregate voids.

\subsection{Integral scenario of soil and landscape evolution} during the last interglacial

Excellent soil preservation (Mikulino is separated from Early Valdai Kukuev soil by $3 \mathrm{~m}$ pedosediment thickness) favored the detailed reconstruction of genesis and evolution of Mikulino paleosol. The next stages of soil development were identified for the Mikulino interglacial:

1. Formation of the lower profile: $A_{1}-A B-$ grassland soil of the first stage of soil formation; identified in soils of balka bottom only.

2. Degradation of upper $A_{1}$ horizon by elluvial process and its transformation into $A_{1} E$, and degradation of the lower part of $\mathrm{A}_{3}$ and transformation into a $\mathrm{ABt}$ horizon, found also in bottom soils.

3. First erosion stage. Gully embedding and its infilling with ABt material eroded from slopes. Accumulation of colluvial sediments during interglacial cooling.

4. Stabilization and formation of second soil profile: light-gray $\mathrm{A}_{2}$ (second humus horizon) $-\mathrm{E}_{2}-\mathrm{ABt}-$ Albeluvisol of a second stage of soil formation; it is represented along the whole catena.

5. Seasonal frozen ground and subsequent erosion in gully bottom - second erosion stage; it is preserved in soils of balka bottom.

6. Formation of upper profile: $A_{1}$ (first humus horizon) $-E_{1}-$ Albeluvisol of the third stage of soil formation; is represented along the whole catena.

Soil formation at the time of the Mikulino interglacial was evolving from grassland Chernozemic in the first stage to forest Albeluvisol (clay illuviation and stagnic processes) later. Soil formation during the second and third stages was unidirectional and resulted in increased textural differentiation. At least twice, the soil formation was interrupted by the accelerated erosion-accumulation processes. The second erosional stage occurred in a cooler environment (as evidenced by seasonal frost). High intensity of soil processes partly erased initial lithologic lamination and formed its own soil "stratigraphy" of horizons. Only a few manifestations are represented, such as a "second" elluvial horizon on the slope and remnants of post-ice lens lamination in the basement of the profile.

Thus, texturally-differentiated forest soils were 
developed in steppe-forest landscapes during the most of the Mikulino interglacial (its optimum and final stage) instead of Chernozemic soils. The proximate analogue of these soils are forest Albeluvisols. This permits us to state that the forest-steppe boundary in the limit of the Middle Russian Plain shifted up to $500 \mathrm{~km}$ south at a time of the Mikulino interglacial. Unfortunately, detailed macro- and micromorphological analyses of paleosols did not permit discrimination between Albeluvisol features developed under deciduous forest of oceanic temperate climate and those of the cooler boreal forests.

Mikulino soil demonstrates a more complicated, prolonged and complete character of development compared to its Holocene analogues. The considerable role of seasonal frost and erosion processes was detected especially at the end stage of Mikulino soil formation. But soil forming processes were not completely interrupted in pedosediments, which buried the interglacial soil. Initial stages of soil formation recurred during short periods when bioclimatic conditions improved and sedimentation rates decreased.

\section{References}

Arslanov, Kh.A., 1987, Radiocarbon: geochemistry and geochronology: Leningrad, Leningrad University Publishers, 300 p. (in Russian).

Bibus, E., 1999, Loess-Paleosol-Sequences in South GermanyStratigraphy, Paleoclimate and Connections with River Terraces: Chinese Science Bulletin, 44, Supplem. 1, 133-138.

Demek, J., Kukla J., 1969, Periglazialzone, Löss und Paläolithicum der Tscheoslowakei: Brno, Czechoslovakia, Tscheoslowaksiche Akademie der Wissenchaften, Geographisches Institut, $158 \mathrm{p}$.

Gerasimenko, N.P., 2004, Development of quaternary zonal landscapes in the territory of Ukraine: Kiev, University of Kiev, synopsis of doctoral thesis in Geography, 41 p. (in Russian).

Glushankova, N.I., 2008, Paleopedogenes i prirodnaya sreda Vostochnoy Evropi v Pleistotzene: Smolensk, Moscow, Magesta, 348 p. (in Russian).

Haesaerts, P., Mestdagh, H., 2000, Pedosedimentary evolution of last interglacial and early glacial sequence in the European loess belt from Belgium to central Russia: Netherlands Journal of Geosciences, Geologie en Mijnbouw, 79, 313-324.

IUSS Working Group WRB (World Reference Base for Soil Resources), 2006, A framework for international classification, correlation and communication: Rome, Food and Agricultural Organization of the United Nations, World Soil Resources Reports, 103, 128 p.
Kukla, G.J., Koci, A., 1972, End of last interglacial in loess record: Quaternary International, 2, 374-383.

Morozova, T.D., 1981, Razvitie pochvennogo pokrova Evropi v pozdnem pleistitzene: Moscow, Nauka, 282 p. (in Russian).

Paepe, R., Vanhoorne, R., 1967, The stratigraphy and palaeobotany of the late Pleistocene in Belgium: Mémoires pour servir à l'explication des cartes géologiques et minières de la Belgique, 8 , Brusseles, $95 \mathrm{p}$.

Pécsi, M., Richter, G., 1996, Löss. Herkunft - Gliederunft - Gliederung - Landschaften: Zeitschift für Geomorphologie (Neue Folge), 98, $392 \mathrm{p}$.

Rivas, J., Ortega, B., Sedov, S., Solleiro, E., Sycheva, S., 2006, Rock magnetism and pedogenetic processes in Luvisol profiles: Examples from Central Russia and Central Mexico: Quaternary International, 156-157, 212-223.

Sycheva, S.A., 1985, On the Mezin pedocomplex geography and evolution within the Oka-Don Plain: Pochvovedeniye, 8, 26-37. (in Russian).

Sycheva, S.A., 1994, Evolution of late Pleistocene catenas of the Middle Russian Upland in the full climatic rhythm "glaciation-interglacial": Pochvovedeniye, 10, 30-40. (in Russian).

Sycheva, S.A, Gunova, V.S., 2004, Results of the investigation of late Pleistocene loess-soil complex in the buried balka system of the Middle-Russian Upland: Moscow, Bulletin Komissii po izucheniu chetvertichnogo perioda, 65, GEOS, 86-101. (in Russian).

Sycheva S.A., Gunova, V.S., Simakova, A.N., 2007, Two variants of the structure of late Pleistocene blanket thickness in peryglacial region of the Russian Plain: Moscow, Fundamental'nie problemi kvartera: itogi izuchenia i osnovnie napravlenia dal'neyshikh issledovaniy, 404-407. (in Russian)

Terhorst, B., Thiel, Ch., Peticzka, R., Sprafke, T., Frechen, M., Fladerer, F.A., Roetzel, R., Neugebauer-Maresch, Ch., 2011, Casting new light on the chronology of the loess/paleosol sequences in Lower Austria: Eiszeitalter und Gegenwart, Quaternary Science Journal, 60, 270-277.

Velichko A.A., Morozova T.D., 1985, Evolution of pedogenesis from a paleogeographic viewpoint: Pochvovedeniye, 11, 76-85. (in Russian).

Velichko, A.A., Gribchenko, Yu.N., Gubonina, S.P., Morozova, T.D., Nechaev, V.P., Syvheva, S.A., Timireva, S.N., Udartsev, V.P., Kalcheva, T.A., Tsatskin, A.I., Chikolini, N.I., 1997, Major features of the fabric of loess-soil formation, in Velichko, A.A. (ed.), LoessSoil formation of the East European Plain: Moscow, Paleogeographia i stratigraphia, Institute of Geography, RAN, 5-24. (in Russian).

Zykina, V.S., 2006, Struktura lessovo-pochvennoy posledovatel'nosti I evolutzii pedogeneza zapadnoy Sibiri: Novosibirsk, Russia, Institute of Geology and Mineralogy, Synopsis of a doctoral thesis in Geology and Mineralogy. (in Russian).

Manuscript received: December 20, 2010.

Corrected manuscript received: February 28, 2012.

Manuscript accepted: March 10, 2012. 